\title{
Books, Pens and Pencils: The Trials of a Victorian Youth
}

\author{
Chantal Cornut-Gentille D'Arcy \\ Universidad de Zaragoza
}

\begin{abstract}
In this survey, we have focussed our attention on the first part of the novel David Copperfield and analyzed how the child hero's natural dispositions are crushed by faulty training. Through his early schooling and youthful experiences, David gains a knowledge of the wretchedness children may suffer in the rigidly practical Victorian socicty which tended to regard little ones as small-scale adults.

By means of the story, Dickens is clearly denouncing the excessive eagerness of utilitarians for efficiency and productiveness in education, and his protests are directed against educators, educational establishments and institutions which ignored the child's need to develop at a natural pace in an atmosphere of affectionate encouragement and happiness.
\end{abstract}

Referring to "these autobigraphical times of ours," Thomas Carlyle had his character, Professor Teufelsdrockh say:

It is maintained by Helvetius and his set that an infant of genius is quite the same as any other infant, only that certain surprisingly favourable influences accompany him through life, especially through childhood, and expand him, while others lie closefolded and continue dunce. Of a truth it is the duty of all men, especially of philosophers to note down with accuracy the characteristic circumstances of their education, what furthered, what hindered, what in any way modified it (1975: 71).

Although we are all conscious of the fact that David Copperfield is not Charles Dickens, it is also common knowledge that Dickens used significant documentary material as the basis of his fiction. By the use of the first person narrative the author plays on two levels, that of the child and that of David -the grown and experienced man affectionately surveying and evaluating the child's progress.

Unlike Oliver Twist, David is not portrayed as the passive hero reacting to obstacles in his path. Rather, the obstacles David encounters are relevant only because of their effect upon him as a character, or in other words, recalling Carlyle's remark, David's experiences are seen as those "influences" which will finally "expand him" and mould him into the mature David.

Although Trevor Blount quite accurately divides the novel into three sections: the hero's childhood, his youth and early manhood and his period of maturity (cited by Trevor Howard, 1975: 15-16) we find that the hero's progress in life is more 
pointedly focussed by John Jones, who cuts the work into two parts: "The Trials of David" and "The Portrait of an Artist" (cited by Philip Hobsbawn, 1981: 123).

In the first chapter of the novel, Dickens presents David as a very little boy indeed and portrays the world around him from the child's perspective. $\mathrm{He}$ is blissfully Happy in his easy little universe with both his mother and Pegotty crooning over him. The only black cloud in his world are the recurrent visits of "the gentleman with the black whiskers" (Charles Dickens, $D C$, p. 70). The child has an instinctive dislike for him and attributes his "uneasy jealousy of him" to "a general idea that Pegotty and I could make much of my mother without any help" (DC, p. 70). Little did he know! However the child was to find out the truth soon enough. On returning from Yarmouth and after the first shock of finding Mr. Murdstone installed as his "new pa" (DC, p. 92), David soon realized that he had partly lost his mother and that the idyllic years he had lived had come to an abrupt end:

God help me, I might have been improved for my whole life. I might have been made another creature perhaps for life by a kind word at that season $(D C$, p. 96$)$.

No kind word is ever to be uttered by Mr. Murdstone, nor is any pleasant communication ever to pass the lips of Miss Murdstone who has now settled into the house to "help" David's mother. Dickens portrays Mr. and Miss Murdstone as repositories of hatred. They establish themselves in the house as despotic jailers, who immediately set about "putting to right" not only the house organization but also the characters of both mother and child. Firmness seems to be the basic cause for the transformation of a once happy household into what has become a "make-believe" and joyless family:

firmness, I may observe, was the grand quality on which both Mr. and Miss Murdstone took their stand. However I might have expressed my comprehension of it at that time, if I had been called upon, I nevertheless did clearly comprehend in my own way, that it was another name for tyranny $(D C$, p. 99$)$.

This firmness clearly recalls the inflexibility of the workhouse board and officials in Oliver Twist. We find that whenever this "grand quality" is displayed, the character in question automatically loses all the capacity for feeling, tenderness and understanding he might have possessed. The case is illustrated in Murdstone's endeavour to strengthen his young wife's weak character and to rectify his stepson's "youthful humours" ( $D C$, p. 98). For example, he warns David of how he would deal with an "obstinate horse or dog": "I make him wince and smart. I say to myself I'll conquer that fellow" (DC, p. 96).

His firmness in teaching or forcing Clara and David to, as Miss Trotwood later puts it, "sing his song" ( $D C$, p. 270) makes of him a despot, but his determination may equally have been prompted by such words as James Mill's:

In whatever degree happiness depends on good conduct, and in whatever degree good conduct depends upon good understanding and good habits, in that same degree do happiness and good conduct depend upon training and education (W. H. Burston, 1973: 267).

If happiness was the end to be achieved, it was never to come, and the process of "training and education" marked the beginning of what John Jones termed "the trials 
of David." Under the systematic oppression caused by the Murdstone's "miscalled firmness," the child remembers how:

I had been apt enough to learn and willing enough, when my mother and I had lived alone together, I can faintly remember learning the alphabet on her knee ... I seem to have walked along a bed of flowers as far as the crocodile book ( $D C$, p. 103).

The fact that David magnifies his early instruction into "a walk along the bed of flowers" can be put down to two reasons. Firstly, in his present state of wretchedness and fear he craves for the placidity and smoothness of the apparently effortless classes under the supervision of his good-natured and lenient mother. Secondly, in portraying such a child-like character as Clara Copperfield, Dickens seems to justify and defend the utilitarian upholding of scholar-teaching, not only as a cheap system for monitorial schools, ${ }^{1}$ but as a good method in itself. Jeremy Bentham, in his Chrestomathia, made it clear that he approved of the "scholar teacher" principle on the grounds that the young understood one another's difficulties better:

"Whatever a child has been taught, he will communicate to his companion better than a master" -agreed the Westminster Review-" . . and his manner of teaching, and the words he employs, will be suited to the capacity of his pupils ... By this single arrangement the great difficulty in the art of education is overcome (E. S. Itskin, 1978: 314).

These words reveal the deep understanding and fellow-feeling that had existed between the child-mother and her little boy and further enhance the contrast between those happy days and the dismal reality of the present lessons which were: " . . presided over nominally by my mother, but really by Mr. Murdstone and his sister" (DC, p. 102).

Gone are the good old days when the child, his eyes heavy with sleep, could plod through his reading book and turn crocodiles into vegetables $(D C$, p. 65$)$ for, says David:

these solemn lessons which succeeded those, I remember as the death blow of my peace, and a grievous daily drudgery and misery $(D C, \mathrm{p} .103)$.

It is obvious that David's lessons, as Dickens depicts them, are a prototype of the method James Mill presented and advocated in his Analysis of the Human Mind as the best form of storing knowledge in the human mind. That is, the mechanical step-bystep learning of facts.

David's personal work consists in memorizing a certain amount of material: "perhaps it is grammar, perhaps history or geography" (DC, p. 103). Dickens is not interested in the subjects as such, but is bent on criticizing or emphasizing the coldness of a method that completely disregards a child's capacity and need for fancy and imagination. The "lesson" entails the oral deliverance of the subject David is supposed to have mastered:

I take a last drowning look at the page as I give it [the book] into her hand and start off aloud at the racing pace while $I$ have got it fresh $(D C$, p. 103). 
The methodology in question is illustrated by James Mill's explanation of the process of memorizing the Lord's Prayer. He writes:

In learning the passage, we repeat it, that is, we pronounce the words in successive order from the beginning to the end. The order of sensation is successive. When we proceed to repeat the passage, the ideas of the words also rise in succession, the preceeding always suggesting the succeeding and no other. OUR suggests FATHER, FATHER suggests WHICH, WHICH suggests ART, and so on, to the end (W. H. Burston, 1973: 173).

This passage exemplifies the mechanical technique of learning based on the psychological theory of Associationism which was to have such a wide effect on schools and institutions of all types throughout the nineteenth century and even into the twentieth century. The influence of the method had become so widespread that, as we see in the case Dickens is presenting, it was even adopted within homes as the best way of training the children.

But in the case of David, the system is presented as a torture session rather than a practical way of acquiring enlightenment and culture. As we have seen, the illusion and fantasy of the crocodile world, together with the warmth of his mother's guidance and company have been replaced by the stern and prosaic obligation of memorizing facts. Worse still, the lessons take place in the terrifying presence of the Murdstones.

The very sight of these two has such an influence over me that I begin to feel the words I have been at infinite pains to get into my head, all sliding away and going I don't know where $(D C$, p. 103).

David is now confronted with what at first appears to be much more practical and matter-of-fact material. But on a second reading of the "appalling sums" Mr. Murdstone invented for the child, it is clear that Dickens is sarcastically turning what could have been useful training into mere feats of mental acrobatics, for the exercises proposed are ludicruously unpractical, unimaginative and totally unconnected with reality.

If $I$ go into a cheese monger's shop, and buy five thousand double-Gloucester cheeses at fourpence halfpenny each, present payment ( $D C$, p. 104).

With reference to the methodology in question, Burston points out that the "Benthamite training was anything but a training in love of 'pleasure" (W. H. Burston, 1973: 85). This statement is clearly illustrated in John Stuart Mill's mild complaint about his early education under his father's supervision:

The element which was chiefly deficient in his [James Mill's] moral relation to his children was that of tenderness ... As regards my own education, I hesitate to pronounce whether I was the gainer or the loser by his severity ... I do not ... believe that fear, as an element in education can be dispensed with, but ... when it predominates so much as to preclude love and confidence on the part of the child to those who should be unreservedly trusted advisers of after years, and perhaps to seal up the fountains of frank and spontaneous communicativeness in the child's nature, it is an evil for which a large abatement must be made from the benefits, moral and intellectual, which may flow from any other part of the education (John Stuart Mill, 1965: 44-45). 
These words were written almost twenty years after David Copperfiela was published, however their effect is that of a colourless replica of the point Dickens wished to make in his vivid and humane rendering of a suffering and oppressed child.

Starting from the psychological principle of Associationism, James Mill developed the theory of "Environmentalism." According to him, environment in general had the power to modify the character and intelligence of any person. He therefore used his "environmentalism" to show up the importance of the family, or at least the personal society in which individuals lived (W. H. Burston, 1973: 237-239).

Dickens, perhaps unconsciously, acknowledges the essential logic of Mill's position for we find that, as in the case of Oliver Twist, the negative influence of the "personal society in which he lived" makes of David "a sullen, dull and dogged boy" (DC, p. 105). But, being a middle-class child, David is more fortunate than the foundling. He discovers in his father's books a means of screening himself from the bare and gruesome reality of the world. He keeps up and develops his fancy as a measure of self-defence and a way of safely dealing with all his stored rancour against the hated ogres. Yet this secret shield proves of little use, for the relationship between David and Mr. Murdstone reaches a climax, and when brutally treated by the latter, David in a moment of desperate rage and panic, lets out and bites him. The child is then savagely beaten.

As we know, David's original happiness is blunted by the Murdstone's trespassing into his little world. Following John Jones's pattern of the "Trials of David" (cited by Philip Hobsbawn, 1981: 123), we now find that, after the altercation with his stepfather, David is launched out into a wider society, and his move signifies a further decline in the child's felicity.

It is unthinkable, of course, that any school to which the austere, arrogant and disciplinarian Mr. Murdstone would consign David could be any other than a place of wretchedness. He is therefore sent to Salem House, a private school near London for the children of the middle-class which is presided over by an ignorant and ferocious brute, Mr. Creakle -a slightly diminished version of Squeers in Nicholas Nickleby.

However, by means of his creation, Dickens manages to portray many characteristics of a typical mid-century private school. The opinions he puts forward are reechoed by John Stuart Mill who believed that:

even in quantity it [education in 1848] is and is likely to remain, altogether insufficient, while in quality, though with some slight tendency to improvement, it is never good except by some rare accident, and generally so bad as to be little more than nominal (E. G. West, 1963: 171).

In chapters five, six and seven Dickens acidly describes the general atmosphere in the school and the subsequent "daily strife and struggle of our lives" (DC, p. 159). Although we find no mention of the lessons studied during that time, it is logical to expect that the standard of education in such "a pernicious humbug," as Dickens later called such institutions, could not be otherwise than deficient. David says:

In a school carried on by sheer cruelty, whether it is presided over by a dunce or not, there is not likely to be much learnt ( $D C$, p. 146).

However, a few scant rays of bright sunshine are cast on the overall gloom. First, there is the account of David's telling stories to the group each evening in bed, which "urged me on somehow," thus making him "an exception to the general body, in so much that I did steadily pick up some crumbs of knowledge" (DC, p. 146). 
Another instance could be the clandestine feeds provided by Steerforth from David's money, and thirdly, the visit of Mr. Peggoty and Ham. For the rest, until David is called home at his mother's death, his schooling at Salem House is shrouded in a dirty atmosphere of ink, tear-blotted copy-books and canings.

Indirectly, it is possible to ascribe the existence of such schools to utilitarian influence for, as a generalization, it may be said that most economists of the time looked upon education from a utilitarian point of view, or at least based their theories on the premises which Adam Smith had laid down.

If such institutions as Salem House were a common feature in the first four decades of the nineteenth century (we canno: forget that Mr. Creakle's school is, in fact a fictional disguise for Wellington House Academy which Dickens had attended as early as 1825), it could be due to the acceptance over the years of the laissez-faire policy which Adam Smith had extended to the educational field. Although the economist recognized the need for some state provision for the education of the poor, he considered that any type of endowment blunted the ordinary forces of a freemarket education and that fee-paying was the one instrument with which parents could keep desirable competition alive between teachers and schools. The results achieved were, in his opinion, much more positive where the market forces were allowed to operate without major restrictions.

Thus, according to Smith, those parts of education which did not depend on endowment were generally the best taught (E. G. West, 1963: 169). Complete failure presumably could only occur at public (i.e. endowed) institutions.

the three most essential parts of literary education, to read, write and account, it still continues to be more common to acquire in private than in public schools, and it very seldom happens that any body fails of acquiring them to the degree in which it is necessary to acquire them (E. G. West, 1963: 146).

James Mill clearly supported Adam Smith's opinion:

\begin{abstract}
"All institutions" -he wrote in the Westminster Review- "for the education of those classes of people who are able to pay for it should be taken out of the hands of public bodies, and left to the natural operation of that free competition which the interests of the parties desiring to teach and to be taught would naturally create" (E. G. West, 1963: 171).
\end{abstract}

Dickens humorously alludes to the free-market of education championed by the utilitarians by later having Mrs. Micawber open a "Boarding Establisment for Young Ladies" ( $D C$, p. 213). It is logical that Mrs. Micawber, in wishing to solve the family problems, should turn to teaching since the total absence of even minimal requirements in setting up a school made the expedient the least costly and burdensome she could have thought of.

Such cases as the ones described by Dickens led one of the Newcastle Commission's London agents, Dr. W. B. Hodgson, to report in 1843:

None are too old, too poor, too ignorant, too feeble, too sickly, too unqualified in any or every way to regard themselves, and to be regarded by others, as unfit for school-keeping ( $P$. Gardner, 1984: 118). 
John Stuart Mill was the only utilitarian who was somewhat doubtful about the competitive market principle in education. He believed that in this field, the customer was not a competent judge of his interests (E. G. West, 1963: 170). But despite his doubts about the efficiency of the market mechanism in education, it was his adherence to the principle of Liberty which brought him round to favour private schools, for, in his opinion: "A general state education is a mere contrivance for moulding people to be exactly like one another" (John Stuart Mill, 1965: 177).

The utilitarian upholding of free competition in education for the middle-class therefore fomented the existence of such schools as Salem House, which, through the incompetence of the "uncultivated to judge cultivation," could come to be profitable, and still more remarkable, could even develop snobbish pretentions, as Dickens wryly illustrates in the scene where Mr. Mell is dismissed for having a mother in an almshouse $(D C$, p. 152-153), and in the flagrant favouritism towards the rich young Steerforth. How such a dismal school could attract a boy from a family as affluent as his appears in Mrs. Steerforth's explanation that though it was not really a fit school for her son, it was desirable that he should be placed with some man who felt and acknowledged his superiority $(D C$, p. 354).

The bargain was simply that her son should be king, and Dickens subtly points out that, in the person of Steerforth, the middle class had power of life and death over anyone belonging to the lower social strata. Thus, all the boys, including little David, bend to his will, and Steerforth can easily defy and then dispose of Mr. Mell, who seemed to be the only person in the school able to withstand the spell of the boy's charm, or to remain aloof from his "position." Such criticism as Dickens's led John Stuart Mill to remark:

it is often affirmed that utilitarianism renders men cold and unsympathizing, that it chills their moral feelings towards individuals (John Stuart Mill, 1972: 18).

Mr. Mell, like most private school teachers of the time, was poor. He was a typical product of the time inasmuch as it was his initial poverty -like that of Nicholas Nickleby- that made him turn to teaching as a last resort. This fact is confirmed by the London Statistical Society who alleged that male teachers:

were men in distressed circumstances who seemed to have taken up the profession as a last resource. Their yearly annual receipts amount to ... a smaller sum than common industry would procure for them in any mechanical and manufacturing employments (Phil Gardner, 1984: 120$)$.

Dickens remarked that he

never could understand the wholesomeness of the moral preached by the abject appcarance and degraded condition of the teachers who plainly said to us by their looks every day of their lives: Boys never be learned . . . be warned in time, by our sunken cheeks, by our primply noses, by our meagre diet, by our acid beer, and by our extraordinary suits of clothes (J. Manning, 1959: 155).

It seems therefore that Dickens wished to show how the instruction provided in the utilitarian free-market of education was all too often in the hands of, either 
ignorant bullies such as Mr. Creackle, whose sole aim was to make money out of the pupils, or of basely exploited teachers such as Mr. Mell.

After the tremendous blow of his mother's death, David fell still further away from his initial happiness, for he was soon

thrown on the wide world, doo'md

to wander and roam

bereft of his parents, bereft of a home (Charles Dickens, 1983: 492).

And he subsequently became, "at ten years old, a little labouring hand in the service of Murdstone and Grinby" ( $D C$, p. 208). In London, David embarks upon what Edgar Johnson called "education in the seamier side of human life," that is, the type of formation that usually and logically follows "domestic education." With his theory of "Enviromentalism" always in mind, James Mill defined social education as that in which society is the institutor (W. H. Burston, 1973: 199).

Dickens loses no time in demonstrating what a tyrant society is, for he immediately portrays the child's situation as the most pitiful possible. The little boy's state of desolation and depression is made all the more acute by his revelation of the "secret agony of his soul":

[I] felt my hopes of growing up to be a learned and distinguished man, crushed in my bosom, the deep remembrance of the same I had, of being utterly without hope now ... of the misery it was to my young heart to believe that day by day what I had learned, and thought, and delighted in, and raised my fancy and my emulation up by, would pass away from me, little by little, never to be brought back any more $(D C$, p. 210$)$.

This combination of autobiographical reminiscences and fiction leads the author to betray not only the deep compassion he felt for "his favourite child," but also the intense moral suffering caused by "the shame I felt in my position" (DC, p. 210).

A little warmth is thrown into the overall desolation of David's life by the startling figures of the Micawbers. However, it is short-lived. When his companions leave for Plymouth in the hope that "something will turn up" ( $D C$, p. 230) little David is left absolutely destitute. He immediately decides to run away from the factory and seek out his aunt Betsey Trotwood.

Footsore, stripped and penniless, David finally arrives at his aunt's. His being promptly taken in and cared for clearly indicates the first step in the reversal of his fortunes. Hence, although this point in the novel does not mark the end of the hero's educational experiences, it certainly denotes that, as happiness settles into David's life again, his initial "trials" suddenly recede to give place to the gradual development and shaping of the mature David.

\section{Note}

1. Both Joseph Lancaster and Dr. Bell claimed the credit for inventing the method of instruction known as the monitorial or mutual system whereby schools could be supervised and run by a minimum of personnel. The information for each lesson was given by the teacher to the senior or more advanced pupils who, in turn, taught their juniors. The utilitarians were convinced that only extended and improved 
education would protect the social order of the country. In their search for widely applicable methods of education, they therefore saw the monitorial schools as a contribution to social stability, as a barrier against crime and disorder, and as a piece of labour-saving machinery. An interesting point to note is the fact that James Mill used the monitorial system within his own family. His system was to instruct John Stuart Mill and then to set John to teach his brothers and sisters, then James Mill would hear the lessons of all of them (John Stuart Mill, Autobiography. Essay on Liberty; Thomas Carlyle, Characteristics. Inaugural Address. Essay on Scott [1874], ed. Charles W. Elliot, The Harvard Classics [New York: Collier and Son, 1965], XXV, 60).

\section{Bibliographical references}

Burston, W. H. James Mill on Philosophy and Education. London: The Athlone Press, 1973.

Carlyle, Thomas. Sartor Resartus (1831). Everyman's Library. London: Dent, 1975.

Dickens, Charles. Bleak House (1853). Harmondsworth: Penguin Books, 1975. . David Copperfield (1849-50). Introduction by Trevor Howard. Harmondsworth: Penguin Books, 1975.

Gardner, Phil. The Lost Elementary Schools of Victorian England. Croom Helm Ltd., 1984.

Hobsbawn, Philip. A Reader's Guide to Charles Dickens. London: Thames and Hudson, 1981.

Itzkin, Elissa S., "Bentham's Chrestomathia: Utilitarian Legacy to English Education," Joumal of History of Ideas (1978), pp. 303-316.

Johnson, Edgar. Charles Dickens, His Tragedy and Triumph: A Biography. 2 vols. London: Hamish Hamilton, 1952.

Manning, J. Dickens on Education. London, Oxford University Press, 1959.

Mill, John Stuart. Autobiography. Essay On Liberty. Thomas Carlyle. Characteristics, Inaugural Address, Essay on Scott (1874), ed. Charles W. Elliot. The Harvard Classics. New York: Collier and Sons, 1965. vol. XXV.

. Utilitarianism. On Liberty and Considerations on Representative Govemment. Everyman's Library, 1910. London: Dent, 1972.

West, E. G. "The Role of Education in the Nineteenth Century: Doctrines of Political Economy," British Joumal of Educational Studies, 12 (1963), 161-172. 